\title{
Thermal Effect of Acute and Chronic Stress on Hepatic and Renal Tissue of the Pacific Sardine, Sardinops sagax caeruleus (Jenyns, 1842)
}

\author{
Efecto del Estrés Térmico Agudo y Crónico Sobre el Tejido Hepático y Renal \\ de la Sardina del Pacífico, Sardinops sagax caeruleus (Jenyns, 1842)
}

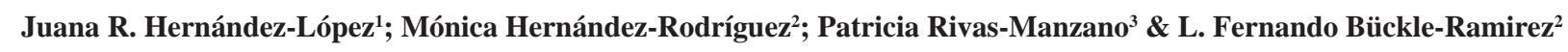

HERNÁNDEZ-LÓPEZ, J. R.; HERNÁNDEZ-RODRÍGUEZ, M.; RIVAS-MANZANO, P. \& BÜCKLE-RAMIREZ, L. F. Thermal effect of acute and chronic stress on hepatic and renal tissue of the Pacific Sardine, Sardinops sagax caeruleus (Jenyns, 1842). Int. J. Morphol., 36(1):212-220, 2018.

SUMMARY: In the thermal range of the Pacific waters, known for the geographical distribution of Sardinops sagax caeruleus (Jenyns, 1842) (Pacific sardine), could be exposed to a stressing temperature environment with dilated effect. This work examines the liver and kidney of sardines acclimated at different temperatures and exposed to the lethal temperature and critical thermal maximum trials. The liver and kidney tissues of Sardinops sagax caeruleus acclimated for 25 days at 19, 21, 23 and $25{ }^{\circ} \mathrm{C}$ were anatomically examined after exposure to acute heat stress (AHS) caused by increasing the water temperature at a rate of $1{ }^{\circ} \mathrm{C}$ per min, and the chronic heat stress (CHS) effect by abruptly exposure to constant water temperature different from that of acclimation (AT). We observed in fish exposed to AHS that the liver tissue had vacuolated or necrotic hepatocytes and infiltration of inflammatory blood cells $\left(25^{\circ} \mathrm{C}\right)$ and the kidney tissue showed degenerative changes in the glomeruli and renal tubules and increased melanomacrophage centers. The CHS effect in liver and renal tissues produced damage signs of pyknosis, apoptosis, necrotic areas, and an increase in melanomacrophage centers as well as outbreaks of bacterial infection. The results demonstrate that $S$. sagax caeruleus did not tolerate an abrupt thermal change of more than $4{ }^{\circ} \mathrm{C}$, independently of the ATs, over $50 \%$ died. The consequences of the experimental acute and chronic thermal stress were histopathological alterations of liver and kidney. It was expected that the chronic stress temperature could produce in fish conspicuous histological changes, and indeed it was the most deleterious.

KEY WORDS: Sardinops sagax caeruleus; Temperature stress-induced; Histopathology

\section{INTRODUCTION}

Sardine (Sardinops sagax caeruleus) is a pelagic species living in subtropical areas, distributed between the latitudes 50 and $60^{\circ} \mathrm{N}$ from the south of Alaska to the Gulf of California, Mexico (Culley, 1971; COSEWIC, 2002). The analyses of sardine captures and temperatures registered throughout 21 years (1981-2002) in San Pedro, Ensenada Bay, Cedros Island and Magdalena Bay, Mexico, enhance the knowledge of three stocks which were divided by thermal barriers. The cold or northern stock was distributed in 13$17{ }^{\circ} \mathrm{C}$, the temperate stock in $17-22^{\circ} \mathrm{C}$ and the warm stock $>22{ }^{\circ} \mathrm{C}$ (Félix-Uraga et al., 2004). This distribution is consistent with the effect of temperature on fish horizontal and vertical distribution (Lynn, 2003).
Temperature stands out as the factor of greatest influence on the behavior and spatial distribution limits of fish (Ziegeweid et al., 2008). A better understanding of changing temperatures on fish is important, and therefore laboratory studies with emphasis on thermal responses, evidence the effect of this factor on the physiology and behavior of the sardine.

The thermal tolerance studies of ectotermic organisms have been evaluated with two methods, static and dynamic. The static or lethal temperature (LT) measures the time of death of the organism exposed to a series of constant temperatures which occur in a relatively

\footnotetext{
${ }^{1}$ CPA-SENASICA, Laboratorio de Bioseguridad Nivel 2. Km 15.5 de la Carretera México-Toluca, Cuajimalpa, Ciudad de México, C. P. 03310, México. ${ }^{2}$ Centro de Investigación Científica y Educación Superior de Ensenada. Baja California, México. Carretera Ensenada-Tijuana 3918. CP. 22860. Apartado Postal 360. Ensenada, Baja California, México. P.O. Box. 434844. San Diego, Ca. 92143-4844, USA.

${ }^{3}$ Universidad Nacional Autónoma de México. Facultad de Ciencias. Circuito Exterior, Ciudad Universitaria. Ciudad de México, C. P. 04510, México.
} 
short time at the upper extreme temperature (Fry et al., 1942; Brett, 1956; Kilgour et al., 1985). The dynamic method involves increasing the test temperatures until an end point is reached (Beitinger et al., 2000). These test are represented by the critical thermal minimum (CTMin) and critical thermal maximum (CTMax), concepts that were proposed by Cowles \& Bogert (1944), which characterize "the thermal point at which locomotory activity becomes disorganized and the animal loses its ability to escape from conditions that will promptly lead to its death".

For more than 60 years, studies of thermal tolerance have been made in different aquatic organisms. The temperature effect in different fish species has been demonstrated with various responses, furthermore affecting the biochemistry, physiology and behavior of the organisms (Brett; Wedemeyer, 1997). However, the effects of stress caused by these types of tests to characterize the thermotolerance responses have not considered the possible histopathological changes in organs such as gill, liver and kidney, among others, that could indicate possible internal damages.

The effect of temperature on tissue can be evaluated by using histopathology, taking into account biochemical, physiological and chronological aspects on tissues morphology. At the histological level, necrotic changes observed in organisms experiencing chronic exposure to stressors can be checked within an organ or specific tissues or cells, evidenced by the morphology of the cell nucleus, nucleolus and cytoplasm (Hinton \& Lauren, 1990). Histopathological responses caused by stress agents (water contamination and parasites, among others) have been identified in the skin, liver, gills, kidney and skeleton of fish (Hinton \& Lauren).

The response of stress on organisms has been evaluated at different levels of biological organization from behavior to cellular level. Different stressors such as ultraviolet radiation, toxins, pathogens, nutritional deficiencies, hypoxia, acidosis, cold and heat, among others, cause cellular stress proteins (Chiang et al., 1989). It has been documented that these proteins (heat-shock proteins HSPs) have a role as molecular chaperones, involved in different processes such as intracellular localization, secretion, regulation, degradation of other proteins, apoptosis and inflammations (Feder \& Hofmann, 1999; Moseley, 2000; Srivastava, 2002).

Fish stress responses can be of different durability depending on the stressor, time of exposure and homeostasis recovery (Wedemeyer; Barandica \& Tort,
2008). Acute stress involves rapid responses and recovery in a short time (hours) after the stressor induction. In teleosts, chronic stress is the result of a constant or repetitive exposure to the stressor that involves long periods of recovery and greater energy expenditure (Barandica \& Tort).

Investigations on the effect of temperature as a stressor indicate that it can produce tissue damage, as noted in rainbow trout, tilapia, and some Cyprinodontidae when they are exposed to temperatures between 30 and $45^{\circ} \mathrm{C}$. In these organisms, the lamellar epithelium of the gills were constricted and the columnar cells collapsed. In addition, the liver presented steatosis, autolytic changes and degenerative processes in the tubular cells of the kidney (Rombough \& Garside, 1977; Davis \& Parker, 1990).

The thermal tolerance of sardines has been documented by Martinez-Porchas et al. (2009) and Martínez-Porchas \& Hernández-Rodríguez (2010). In these studies, the fish were exposed to two different fluctuating thermal cycles according to the temperatures recorded in the north, where the colder stock is located (San Pedro, California; SPc, 13 to $18{ }^{\circ} \mathrm{C}$ ) and in the south, where the temperate stock thrives (Cedros Island, Mexico; CIc, 18 to $23{ }^{\circ} \mathrm{C}$ ). The SPc and CIc stock thermal preference interval was 17.1-19.9 and 16.0-18.8 ${ }^{\circ} \mathrm{C}$, while the lethal temperatures interval (LT50) was 7.7-25.6 and 6.9-24.3 ${ }^{\circ} \mathrm{C}$, and the critical limits CTMax and CTMin were 7.1-32.2 and 5.5-30.4 ${ }^{\circ} \mathrm{C}$, respectively. Thermal tolerance in sardines was also investigated by Pribyl et al. (2016), based in the critical thermal maximum and minimum of the northern sardines acclimated at $15^{\circ} \mathrm{C}$ and $17^{\circ} \mathrm{C}$ to determine the "ideal" temperature range.

The increase of the ocean surface temperature, the "El Niño" phenomenon and the food abundance affects the reproduction and distribution of the sardine (Hammann et al., 1988; Bakun \& Broad, 2003; Félix-Uraga et al.). The study by Pribyl et al. indicated that Pacific sardine of the northern stock has an ideal physiological thermal range depending on the acclimation temperature, based on an analysis of tissue and blood samples. Little is known how the temperature stressor affect sardines at morphological levels, biochemical and physiological processes (Martínez-Porchas et al., 2009). In this work, we study the effect of acute and chronic heat stress on the histopathology of liver and kidney in Sardinops sagax caeruleus with two methods utilized in the evaluation of thermal tolerance in laboratory conditions: critical thermal maximum and the upper lethal temperature. 


\section{MATERIAL AND METHOD}

Sardines were captured in the summer at the port of Ensenada, Baja California, Mexico, ( $31^{\circ} 52^{\prime}$ Lat. North. $116^{\circ}$ $37^{\prime}$ Long. West) and transported in polyethylene bags with sea water saturated with oxygen to the Ecophysiology Laboratory of the Aquaculture Department of CICESE (Center for Scientific Research and Higher Education of Ensenada).

To determine the thermal stress experiments and the acclimation temperatures, we used the sardine distribution stock adapted to a 17 to $22{ }^{\circ} \mathrm{C}$ range described by FélixUraga $e t$ al. The temperature tolerance limiting the species distribution area $\left(25^{\circ} \mathrm{C}\right)$ was determined in our laboratory in previous experiments (unpublished data).

The sardines $(\mathrm{N}=352)$ (weight $39.44 \pm 4.81 \mathrm{~g}$; and length $15.74 \pm 0.51 \mathrm{~cm}$ ) were distributed in eight $380 \mathrm{~L}$ circular tanks ( $\mathrm{N}=44$ fish per tank) at the collection temperature of $18^{\circ} \mathrm{C}$. Afterwards, the initial temperature of each pair of tanks was increased $1{ }^{\circ} \mathrm{C}$ per day until reaching the acclimation temperatures (AT) of 19,21, 23 and 25 with a mean deviation $\pm 0.51^{\circ} \mathrm{C}$, where they remain for 25 days. The water flow rate was $47.5 \mathrm{~L}^{\mathrm{h}-1}$ to change the total volume three times in $24 \mathrm{~h}$. Each water temperature was maintained with a 1000 Watts titanium heater connected to an electronic controller. The control condition of $19{ }^{\circ} \mathrm{C}$ is in the sardine thermal preference $17-20{ }^{\circ} \mathrm{C}$ interval found by MartínezPorchas $e t$ al. The tanks were cleaned daily to remove feces, food remnants and dead fish. Oxygen content and temperature were recorded with an YSI model 85 multiparameter (Yellow Spring, Ohio). Average and standard deviation of water temperature and oxygen concentration during the acclimation period are shown in Table I. Organisms were fed with a diet made of trout with $50 \%$ protein at a rate of $2.5 \%$ of their body weight in two daily rations. Before the start of each experiment, the fish were kept without food for $24 \mathrm{~h}$ to avoid metabolic interference.

At the end of the acclimation period, randomly selected organisms of each temperature were either exposed to critical thermal maximum CTMax-acute heat stress (AHS) or to the lethal temperature (LT50)-chronic heat stress (CHS) utilized in the studies of thermic tolerance in aquatic organisms. Four sardines from the control group of each AT, were sacrificed with an anesthetic overdose (2phenoxyethanol) to remove the liver and kidney for histological procedures. The histopathological analysis was used to contrast and to determine which experimental temperature exposure was the most deleterious for the liver and kidney of sardines.
For the study of AHS (CTMax), we used a $56 \mathrm{~L}$ aquarium containing $21.5 \mathrm{~L}$ volume of seawater and a 1000 Watt heater fixed to an aeration stone to spread the heat evenly. To maintain a continuous temperature rise no water flow was added. The experiment began when the aquarium water reached the acclimation temperature, then two fish were incorporated. The temperature increase of $1{ }^{\circ} \mathrm{C} \mathrm{min}-1$ was started after 20 min to reduce the impact stress caused by handling. These experiments were repeated six times with different fish for each acclimation temperature. All fish lost equilibrium (LE) during the experiment which defines the critical point of CTMax (Paladino et al., 1980), and four random sardines were sacrificed to dissect the liver and kidney with a scalpel to assess the histological changes produced by the effect of AHS.

The effect of CHS (LT50) was evaluated based on the model of Kilgour et al. Five aquaria ( $56 \mathrm{~L}$ ), each with three fish, were abruptly exposed to the chronic heath stress at different constant temperatures (Table II) and with a continuous $120 \mathrm{ml} \mathrm{min}^{-1}$ water flow to refill the total volume approximately three times in $24 \mathrm{~h}$ to eliminate the metabolites produced by fish waste. Aeration was continuous and the water temperature was maintained with a 1000 Watt immersion heater connected to an electronic controller to keep the temperature almost constant $\left( \pm 0.1\right.$ to $\left.0.3^{\circ} \mathrm{C}\right)$. Each trial was carried out twice $(\mathrm{N}=24-30)$. Experimental temperatures for each condition were set up with the difference in the temperature interval (i.e. $6^{\circ} \mathrm{C}$ ) used for the acclimation $\left(19-25^{\circ} \mathrm{C}\right)$. This difference was added to each AT, and according to the fish tolerance, it was increased or decreased $1{ }^{\circ} \mathrm{C}$ (Table II). When each fish died, the time was recorded and immediately the liver and kidney was dissected for histological analysis.

The entire kidney $(\mathrm{N}=30)$ and only the posterior part of the liver were removed to avoid contamination with the gallbladder and its ducts (Lagler et al., 1984). The samples were fixed in $10 \%$ formalin for $24 \mathrm{~h}$, later changed to $70 \%$ alcohol and treated conventionally for paraffin embedded tissues with an automated processor (Leica brand Histokinette model TP1040). Only the middle part of the kidney was analyzed because the cephalic region contains mainly haematopoietic tissue. The renal and hepatic samples were cut $4 \mathrm{~mm}$ thick on a microtome American Optical (Spencer model 820). Three medial and sagittal cuts of each organ were stained with the Hematoxylin-Eosin technique (Shaw \& Battle, 1957) and preserved with synthetic resin (Cytoseal). The histological preparations were analyze in a Zeiss microscope (model Axiolab). The histological description of acclimated fish at different temperatures and then exposed to acute and chronic heat stress will be represented as AT + AHS or CHS. 
Table I. Values of temperature and oxygen concentration during the acclimation period of Sardinops sagax caeruleus.

\begin{tabular}{ccc}
\hline $\begin{array}{c}\text { Acclimation } \\
\text { temperature }\left({ }^{\circ} \mathrm{C}\right)\end{array}$ & $\begin{array}{c}\text { Temperature } \\
\left({ }^{\circ} \mathrm{C}\right)\end{array}$ & $\begin{array}{c}\text { Oxygen concentration } \\
\left(\mathrm{mg} \mathrm{O}_{2} \mathrm{~L}^{-1}\right)\end{array}$ \\
\hline 19 & $18.97 \pm 0.35$ & $7.68 \pm 0.82$ \\
21 & $20.90 \pm 0.42$ & $6.82 \pm 1.14$ \\
23 & $22.88 \pm 0.63$ & $6.71 \pm 1.10$ \\
25 & $24.85 \pm 0.64$ & $6.60 \pm 1.07$
\end{tabular}

Average \pm Standard deviation.

Table II. Experimental temperatures at which S. sagax caeruleus acclimated to four temperatures were abruptly exposed to the chronic heath stress (CHS).

\begin{tabular}{cccccc}
\hline AT $\left({ }^{\circ} \mathrm{C}\right)$ & \multicolumn{5}{c}{ Experimental temperature $\left({ }^{\circ} \mathrm{C}\right)$} \\
\hline $19(4)$ & $23(6)$ & $24(6)$ & $25(6)$ & $26(6)$ & $27(6)$ \\
$21(4)$ & $25(6)$ & $26(6)$ & $27(6)$ & $28(6)$ & - \\
$23(4)$ & $26(6)$ & $27(6)$ & $28(6)$ & $29(6)$ & - \\
$25(4)$ & $27(6)$ & $28(6)$ & $29(5)$ & $30(6)$ & - \\
\hline
\end{tabular}

AT; acclimation temperature. The parenthesis indicates the number of fish used for histology.

Four histological cuts of the fish liver from each condition AT and AHS conditions, were examined to measure 35 to 38 hepatocytes nuclei in a microscope Zeiss Scope A1 through the CarlZeiss/Zen 2012 program. All data were evaluated for normality using Kolmogorov-Smirnov test. A t-test (Sigma Stat 3.5) was applied to compare the effect of the temperature over CTMax, the hepatocytes nuclei linking the controls (AT) and the respective acute heat stress (AHS) condition. The hepatocytes nucleus diameters of the liver from fish that were exposed at AHS and the control group were compared with an ANOVA test. A multiple comparisons test (Dunnett's method) $19^{\circ} \mathrm{C}$ versus 21,23 y $25^{\circ} \mathrm{C}$ was used taking into account that the AT of $19^{\circ} \mathrm{C}$ differs only $1^{\circ} \mathrm{C}$ which is the value of the final preferendum reported by Martínez-Porchas et al. The Spearman-Karber program was used to calculate the LT50.

\section{RESULTS}

The liver of the control organisms (AT) unexposed to AHS and CHS acclimated to $19,21,23$ and $25^{\circ} \mathrm{C}$ showed the normal arrangement of hepatocytes and sinusoids (Fig. 1A), and the presence of scarce haematopoietic cells and melanomacrophages. Hepatocytes with changes in the nucleus, nucleolus and distended cytoplasmic appearance were observed in sardines acclimated at $25^{\circ} \mathrm{C}$. The nucleus diameter increased in the AT the 19 and $23^{\circ} \mathrm{C}$ from 10.01 to $11.34 \mu \mathrm{m}$ (Table III) with significant differences $(\mathrm{P} \leq 0.001)$ qualitatively. The nucleolus appeared twice its size (Fig. 1B and C).
In the control fish, the kidney had structures with normal appearance (Fig. 2A). In all acclimation conditions, haematopoietic tissue and melanomacrophage centers slightly augmented.

Acute Heat Stress (AHS). The equilibrium loss responses of acclimated sardines at $19,21,23$ y $25{ }^{\circ} \mathrm{C}$ were respectively at $30.8 \pm 0.79,31.6 \pm 0.41,31.8 \pm 0.83$ and $32.8 \pm 0.65{ }^{\circ} \mathrm{C}$, with significant differences $(\mathrm{P}<0.05)$, except at 21 and $23{ }^{\circ} \mathrm{C}$.

The histological description of the liver and kidney corresponds to the sardine equilibrium loss. In histological preparations from the liver, vacuoles in the hepatocytes and leucocytes within sinusoids were observed (Fig. 1E). Sardines acclimated at $25^{\circ} \mathrm{C}+\mathrm{AHS}$, had necrotic areas and infiltration of inflammatory cells (Fig. $1 \mathrm{D}$ and E).

The histological sections of the kidney, had haematopoietic tissue (Fig. 2B) and melanomacrophage centers (Fig. 2D). All organisms exposed to the chronic heath stress showed pyknotic nuclei in renal tubules (Fig. 2C); the Bowman intercapsular space is bigger compared with the control organisms, and shrunken glomeruli (Fig. 2C) were also identified at $21^{\circ} \mathrm{C}+\mathrm{AHS}$. The kidney cuts of the sardines that were acclimated at 23 and $25^{\circ} \mathrm{C}$ and subsequently exposed to AHS, had degenerating or degenerated glomeruli, sometimes empty Bowman intercapsular space with debris (Fig. 2D).

The comparison between the hepatocyte diameters of the control groups versus AHS showed differences between $21^{\circ} \mathrm{C}(\mathrm{P}=0.018)$ and $23^{\circ} \mathrm{C}(\mathrm{P} \leq 0.001)$. The nucleus diameter of the hepatocytes increase between the ATs and the AHS in 19 and $21^{\circ} \mathrm{C}$, and it decrease between the ATs and AHS at 23 and $25^{\circ} \mathrm{C}$ conditions (Table III). The liver hepatocyte diameter of the control group of fish acclimated at $19^{\circ} \mathrm{C}$ were significantly different $(\mathrm{P} \leq 0.05)$ from those acclimated at 21,23 and $25^{\circ} \mathrm{C}$.

Chronic Heat Stress (CHS). Table IV shows the chronic heat stress trial of the acclimation versus experimental temperatures, where $50 \%$ of the fish died. The effect of CHS in the liver and kidney was similar to the organisms exposed to AHS, but the degree of injury was related to the experimental temperature and exposure time.

In organisms acclimated at 23 to $25^{\circ} \mathrm{C}$ and exposed to 26 to $30^{\circ} \mathrm{C}$ experimental temperature, the alterations found in the liver by chronic heat stress exposure were: abundant and extensive necrotic areas (Fig. 1F), increased melanomacrophages dispersion, clots into the vessels (Fig. $1 \mathrm{G})$, pyknotic and apoptotic hepatocytes (Fig. 1H), 


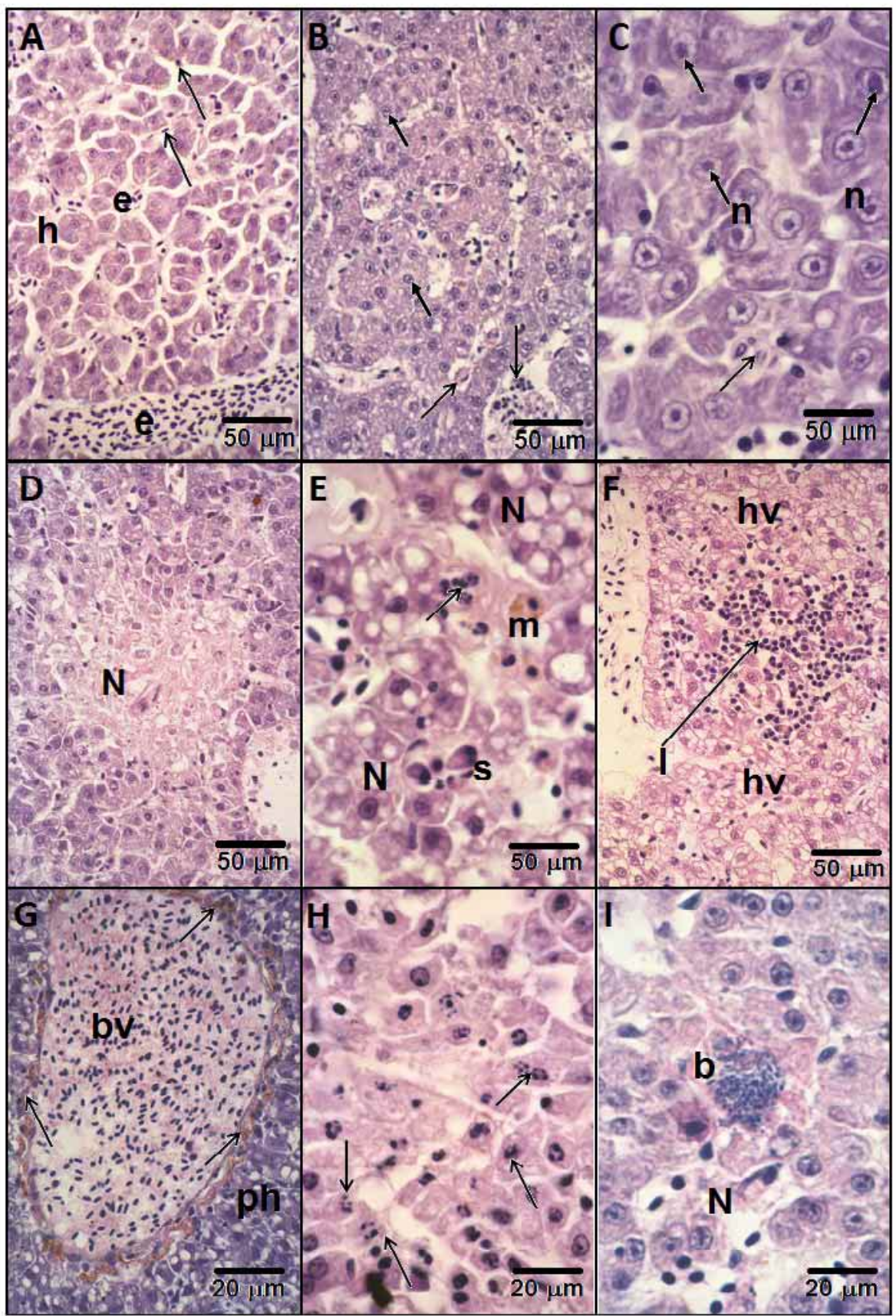

Fig. 1. Representative cross section, of the liver of $S$. sagax caeruleus in controls and exposed to acute and chronic heat stress. Hematoxylin-Eosin. A) Control $19{ }^{\circ} \mathrm{C}$. Normal arrangement of hepatocytes (h) and sinusoids (arrow), erythrocytes (e), 500X; B) In acclimation temperature (AT) of $25^{\circ} \mathrm{C}$, hepatocytes with changes in nucleus (black arrow) and cytoplasmic appearance, leucocytes within sinusoids (arrow) 500X; C) $25^{\circ} \mathrm{C} \mathrm{AT}$, hepatocytes with an increase in the size of the nucleus (n) and nucleolus (black arrow ), in the cytoplasm the organelles appear distended, inflammatory cell (arrow) 1250X; D) AHS, necrotic area (N) 500X; E) AHS, vacuolated and necrotic hepatocytes $(\mathrm{N})$, infiltrated inflammatory cells (arrow), leucocytes within sinusoids (s), melanomacrophage cell (m), 1250X; F) CHS, vacuolated hepatocytes (hv), necrotic area with inflammatory cells (I), 500X; G) CHS, unusual presence of melanomacrophages (arrow) surrounding a big blood vessel (bv) with a clot. Pyknotic and vacuolated hepatocytes (ph), 500X; H) CHS, area with hepatocytes in apoptosis (aa), observe chromatin fragmentation (arrow), 1250X, I) CHS, a focus of bacterial infection (b), necrotic hepatocytes $(\mathrm{N})$, only in organisms acclimated at $25^{\circ} \mathrm{C}$ and exposed to 26 to $30{ }^{\circ} \mathrm{C}, 1250 \mathrm{X}$. vacuolated hepatocytes (Fig. $1 \mathrm{~F}$ and G), and bacterial infection (Fig. 1I) sometimes surrounded by hepatocytes forming nodules.

The microscopic changes in kidney tissue of fish from each acclimation temperature and exposed to different experimental temperatures were: extensive glomeruli and tubular necrosis (Fig. 2E), scattered cells in melanomacrophage centers (Fig. $2 \mathrm{~F}$ ), extravased erythrocytes (Fig. $2 \mathrm{G}$ ) and bacterial infection (Fig. $2 \mathrm{H})$. At the cellular level, the tubular cells showed pyknosis and cytoplasmic lysis (Fig. 2G up) or chromatin fragmentation (Fig. 2G lower). Alterations in the kidney increased with rising experimental temperature and exposure time. In some kidney tissue, necrotic coagulation, complete loss of tissue organization and cells limits were observed, and all the nuclei were pyknotic (Fig. 2H). The sardines that were exposed from 23 to $30^{\circ} \mathrm{C}$ (Fig. 2I), had the greatest frequency of histological changes. Additionally, in liver and kidney tissue of the highest temperature stress exposure, the melanomacrophage centers were disaggregated because the cells lost its pigments and fibroblasts nearby in the perivascular area.

The percentage of survival of sardines during the acclimation period at temperatures of 19, 21, 23 and $25^{\circ} \mathrm{C}$ was 98.8, 94.3, 92.1 and $49 \%$, respectively. External responses of sardine exposed to acute and chronic heat stress were desquamation and mucus production. 


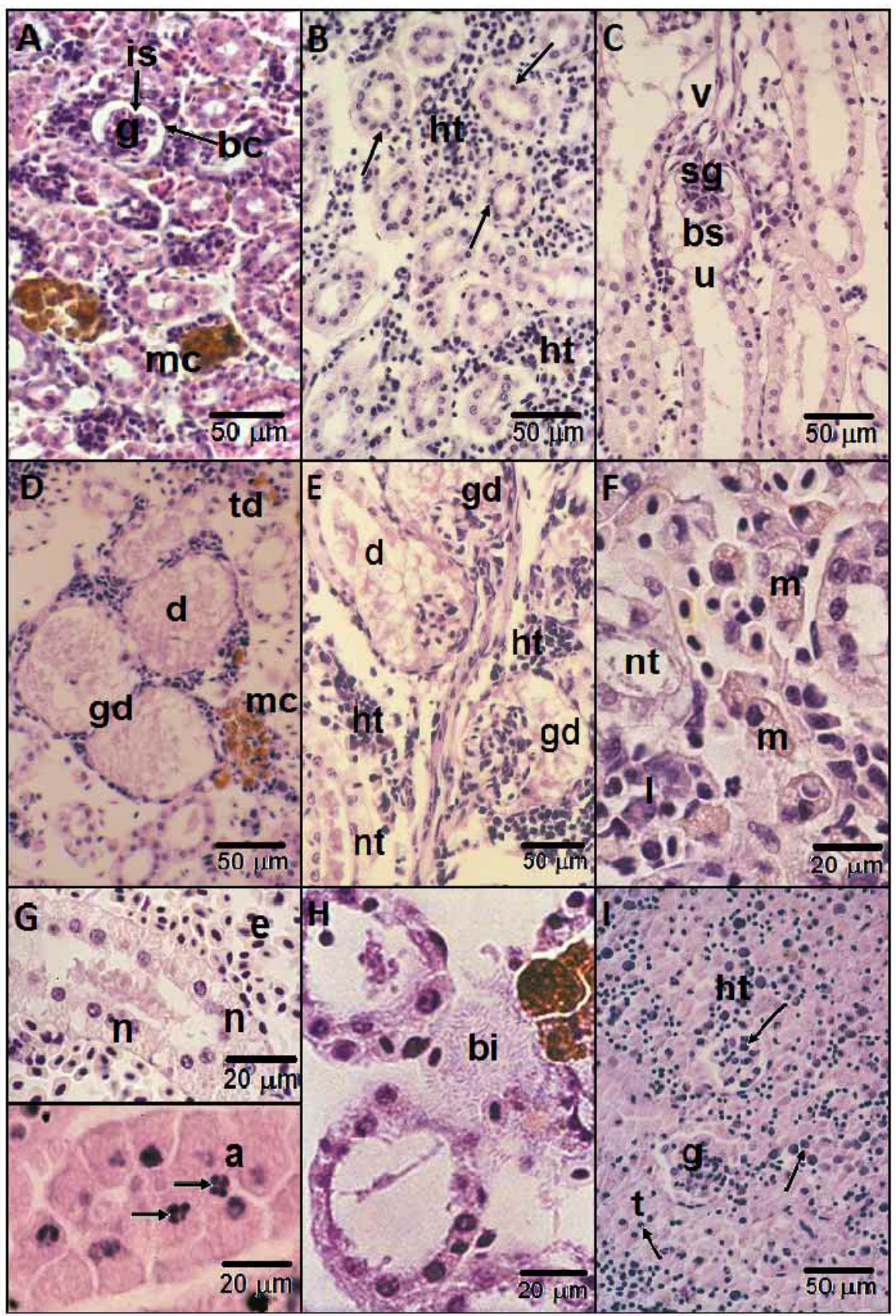

Fig. 2. Representative saggital section of the kidney of $S$. sagax caeruleus in controls and exposed to acute and chronic heat stress. Hematoxylin-Eosin. A) Control 19 ${ }^{\circ} \mathrm{C}$, melanomacrophage center (mc), glomeruli (g), intraglomerular space (is), Bowman capsule (bc); B) AHS, pyknotic nuclei (black arrow), in renal tubules, increased haematopoietic tissue (ht); C) AHS, renal corpuscle in degeneration with shrunken glomeruli (sg) and augmented Bowman space (bs), observe vascular pole (v) and urinary pole (u), 500X; D) AHS, tubule in degeneration (td), some glomeruli in complete degeneration (gd), debris (d), and melanomacrophage center (mc), 500X; E) CHS, a group of renal corpuscles in degeneration with retracted glomeruli (gd) and debris (d), haematopoietic tissue (ht), necrotic tubule (nt) 500X; F) CHS, scattered melanomacrophages $(\mathrm{m})$ with vacuoles and phagocyted material, inflammatory cells (I), and necrotic tubule (nt) 1250X; G) CHS, both types of cell death in tubules, cells with necrotic changes (n) and apoptotic changes (d), observe lyses in necrotic cells, and detached apoptotic tubular cells with chromatin fragmentation (black arrow), extravased erythrocytes (e) in the intertubular space, $1250 \mathrm{X} ; \mathrm{H}$ ) focus of bacterial infection (bi); I) CHS, in some cases, the kidney lost the tissue organization, all the nuclei are pyknotic (black arrow), rests of tubules (t), glomeruli $(\mathrm{g})$ and haematopoietic tissue (ht) could be observed, 500X.

Table III. Test comparison of the hepatocytes nucleus diameter of $S$. sagax acclimated at different temperatures (AT) and exposed to the acute heath stress (AHS).

\begin{tabular}{lcrrrcc}
\hline Condition & ${ }^{\circ} \mathrm{C}$ & $\mathrm{N}$ & $\mathrm{M}(\mu \mathrm{m})$ & $\mathrm{SD}$ & $\mathrm{t}$ & $\mathrm{P}$ \\
\hline AT & 19 & 35 & 10.012 & 0.995 & & \\
AHS & 19 & 38 & 10.107 & 0.759 & $\mathrm{t}=-0.459$ & $(\mathrm{P}=0.647)$ \\
AT & 21 & 35 & 11.129 & 0.908 & & \\
AHS & 21 & 36 & 11.605 & 0.740 & $\mathrm{t}=-2.426$ & $(\mathrm{P}=0.018)$ \\
AT & 23 & 35 & 11.347 & 0.938 & & \\
AHS & 23 & 35 & 10.323 & 0.735 & $\mathrm{t}=-5.085$ & $(\mathrm{P}=0.001)$ \\
AT & 25 & 37 & 11.040 & 1.222 & & \\
AHS & 25 & 36 & 10.557 & 0.881 & $\mathrm{t}=1.932$ & $(\mathrm{P}=0.057)$ \\
\hline
\end{tabular}

$\mathrm{N}$, number of measurements; $\mathrm{M}$, mean; SD, Standard deviation; t, value; $\mathrm{P}$, probability. 
Table IV. Chronic heat stress experiments (CHS). Time (min) when $50 \%$ of the experimental fish $S$. sagax caeruleus sample died after being exposed to different temperatures.

\begin{tabular}{ccccccccc}
\hline $\begin{array}{c}\text { Acclimation } \\
\text { temperatures }\left({ }^{\circ} \mathrm{C}\right)\end{array}$ & \multicolumn{7}{c}{ Experimental temperatures $\left({ }^{\circ} \mathrm{C}\right)$} \\
\hline & 23 & 24 & 25 & 26 & 27 & 28 & 29 & 30 \\
19 & 1252 & 749 & 730 & 698 & 79 & - & - & - \\
21 & - & - & 610 & 453 & 454 & 242 & - & - \\
23 & - & - & - & 470 & 279 & 231 & 233 & - \\
25 & - & - & - & - & 216 & 215 & 120 & 92 \\
\hline
\end{tabular}

\section{DISCUSSION}

The effect of temperature has been studied in fish evaluating their tolerance through the LT50 (static method) and CTMax (dynamic method); however, the damage of this factor concatenated with stress in different organs of an organism was unknown. In this study, we subjected sardines (S. sagax caeruleus) to four acclimation temperatures, and only those acclimated at $25^{\circ} \mathrm{C}$, showed liver tissue changes in the nuclei and nucleoli.

When fish are under environmental stress, they can undergo internal anatomical changes that are detrimental or adaptive, and if these alterations are not corrected or compensated, the body weakens, losing its ability to cope with other stressors (Wedemeyer). S. sagax caeruleus was able to compensate for the heat change throughout the acclimation process; however at $25^{\circ} \mathrm{C}$, the results suggest that the hepatic cells lost their adaptation capability. The change of nucleoli could be a hallmark of damage because the nucleolus has been considered as a stress sensor (Mayer \& Grummt, 2005). Indeed, at $25^{\circ} \mathrm{C}$ acclimated temperature fish survival was $49 \%$, while in the other temperatures, it was higher than $90 \%$.

Sardines acclimated in the 19 to $25^{\circ} \mathrm{C}$ interval and exposed to acute stress formed more melanomacrophage centers, pyknosis and degenerative changes (necrotic) in the glomeruli and tubules. Similar changes such as cell necrosis in renal tissue were observed in other stressors studies, in the Anguilla anguilla (Olivereau \& Olivereau, 1977), Oncorhynchus tshawytscha (Kiryu \& Moffitt, 2001), Chana punctatus (Bhuiyan et al., 2001), Mugil sp., Cyprinus carpio and Barbas sp. (González de Canales et al., 2003). However, high stocking density cultivation as a stressor on Paralabrax maculatofasciatus did not reveal histological necrosis in the kidney (Zacarías et al., 2009).

In kidney and liver tissues of sardines exposed to chronic heat stress, the histopathogical changes were more pronounced with the temperature increase. The degenerative changes included necrotic signs (pyknotic nuclei and cytoplasmic lysis) in glomeruli and renal tubules as well as hepatocytes. In addition to the necrotic changes, emerge apoptotic alteration like chromatin fragmentation, cytoplasmic condensation and detached cells.

Cell death found in the tissues of fish exposed to acute and chronic heat stress can be considered a physiological response to eliminate those that have been damaged, and indeed the histological cuts reveal more melanomacrophages and neighboring macrophagic cells. In cell death processes, apoptosis and necrosis are involved (Takashima \& Takashi, 1995). Apoptosis is a genetic programmed cell death, an essential mechanism for normal tissue function and development (Studzinski, 1999). When cells lose their ability to undergo apoptosis in response to a physiological stimulus, or when apoptosis increase dramatically, the result can be detrimental (Jacobson \& McCarthy, 2002). Apoptotic cell death involves shrinkage of the cell, chromatin fragmentation, formation of membrane-bound apoptotic bodies and rapid phagocytosis by neighbouring cells (Takashima \& Takashi). In this study, extensive death by apoptosis was observed in hepatic and renal tissues undergoing chronic extreme thermal stress.

Necrosis produced in the tissues of organisms is the state in which the cells are damaged and eventually die. In the nucleus, hipercromatosis, pyknosis, and cariolysis occur and the cytoplasm becomes homogeneously stained with eosin (Takashima \& Takashi). In this state, the cell contents are released into the extracellular fluid irritating the adjacent cells causing inflammation (Studzinski).

Hinton \& Lauren argued that internal kidney lesions are considered good indicators of contamination because adjacent to the renal tissue lies the adrenal tissue that synthesizes the stress hormones adrenaline, noradrenaline and glucocorticoids released when an animal experiences several types of stress. The kidney tissue changes found in the sardines in our study could be also used as indicators of thermal stress effect. 
Anderson (1990) argues that stress can compromise an animal's defense mechanisms, affecting the physiological processes that constitute the specific and nonspecific immune responses, and thereby increasing the vulnerability of organisms. Our morphological study revealed the participation of elements of nonspecific immune response such as humoral, tissue and cell factors (Fernández et al., 2002). The skin responses of sardines exposed to acute and chronic heat stress showed desquamation and mucus production. At the histological level, we found in the liver and kidney increase melanomacrophage centers and haematopoietic tissue. Melanomacrophage aggregates have been suggested as indicators of health status in wild fish and may contain not only melanin, but also haemosiderin and lipofuscin (Hinton \& Lauren). These authors suggest that the aggregates vary in number and size caused by the effect of food insufficiency, toxicity, disease and age, among others. In this research, more melanomacrophage centers were observed in relation to the temperature exposure, but in the extreme heat, they disaggregated and lost pigments. Additionally, histology of sardines acclimated at 23 and 25 ${ }^{\circ} \mathrm{C}$ that were exposed to the $\mathrm{CHS}$, had bacterial infection and infiltration of inflammatory cells.

In the extreme of the thermal stress condition, the liver and kidney tissues had more fibroblasts in the perivascular area. According to Takashima \& Takashi, fibroblasts are a characteristic of an inflammatory response as a protective reaction to physical stimuli, chemicals and parasites that strongly affect the tissue. During the defense reaction of the organisms, macrophages, histiocytes and monocytes are increased at the site of inflammation process that ends with the hyperplasia of fibroblasts (Takashima \& Takashi). The most conspicuous histopathology changes observed in the liver and kidney were in sardines exposed to chronic heat stress.

The purpose of research of thermal tolerance lies in knowing the temperature(s) at which a species grows better and in assessing its adaptive capability. Our results highlight the sardines' ability of acclimation to new thermal conditions, provided that the changes are gradual. The experimental responses to physiological adaptation were evident in the acclimation process, but fish exposed to chronic heat stress did not tolerate an abrupt thermal change of more than $4{ }^{\circ} \mathrm{C}$, independently of the ATs, over $50 \%$ died. Based on the results of this study and considering that the temperate stock was distributed in 17 to $22^{\circ} \mathrm{C}$ (Félix-Uraga et al.), it is likely that with continuing global warming, sardines will move further north to find temperatures near its optimum range of 16 to $20^{\circ} \mathrm{C}$ as reported by Martinez-Porchas et al. (2009). In S. sagax caeruleus acclimated to thermal fluctuations, the upper incipient lethal temperature was near $25^{\circ} \mathrm{C}$ (Martinez-Porchas et al.) which could explain the low survival obtained in fish that were acclimated at the temperature of $25^{\circ} \mathrm{C}$, and where the most notable histopathological changes were observed. Martínez-Porchas et al. and Pribyl et al. conclude that the Pacific sardine probably has a limited ability to tolerate warm temperatures. In this context, the present study seems to confirm that assumption because the survival rate was less than $50 \%$ for sardines acclimated at $25^{\circ} \mathrm{C}$.

The results of this study show that the tests used to evaluate thermal tolerance by static or dynamic method cause alterations in the tissues of organisms, as observed in the liver and kidney of the Pacific sardine. This effect can be magnified if organisms acclimate near sublethal temperatures.

ACKNOWLEDGMENTS. This work was supported by the Federal Government of México with regular funding of the Centro de Investigación Científica y Educación Superior de Ensenada (C.I.C.E.S.E.) Center for Scientific Research and Higher Education of Ensenada, Baja California, México. Proyect 6779. The authors thank Michel Bayne Richardson for the sardines used in this investigation. We also extent our gratefulness to Francisco Valenzuela, Luis Murillo, Adrian Celaya, Norberto Flores and Carlos Carballo for their technical support. The authors thank Yanet Guerrero Rentería for his support with histology and Dafne Estefany Bonilla Cerquedo for improving the images.

HERNÁNDEZ-LÓPEZ, J. R.; HERNÁNDEZ-RODRÍGUEZ, M.; RIVAS-MANZANO, P. \& BÜCKLE-RAMIREZ, L. F. Efecto del estrés térmico agudo y crónico sobre el tejido hepático y renal de la Sardina del Pacífico, Sardinops sagax caeruleus (Jenyns, 1842) Int. J. Morphol., 36(1):212-220, 2018.

RESUMEN: En el rango térmico de las aguas del Pacífico, conocido por la distribución geográfica de Sardinops sagax caeruleus (Jenyns, 1842) (sardina del Pacífico), esta especie podría estar expuesta a un ambiente de temperatura estresante con efecto dilatado. Este trabajo examina el hígado y el riñón de las sardinas aclimatadas a diferentes temperaturas y expuestas a la temperaturas letales y crítica máxima. Los tejidos hepático y renal de Sardinops sagax caeruleus aclimatadas durante 25 días a $19,21,23$ y $25{ }^{\circ} \mathrm{C}$ se examinaron anatómicamente después de la exposición al estrés de calor agudo (AHS) causado por el aumento de la temperatura del agua a una velocidad de $1^{\circ} \mathrm{C}$ por minuto , y el efecto de estrés de calor crónico (CHS) por la exposición brusca a una temperatura constante del agua diferente a la de la aclimatación (AT). Observamos en peces expuestos a AHS que el tejido hepático tenía hepatocitos vacuolados o necróticos y la infiltración de células sanguíneas $\left(25^{\circ} \mathrm{C}\right)$ y el tejido renal presentaba cambios degenerativos en los glomérulos y túbulos renales y aumento de centros de melanomacrófagos. El efecto CHS en los tejidos hepático y renal produjo signos de daño de picnosis, apoptosis, áreas necróticas y un au- 
mento en los centros de melanomacrófagos, así como brotes de infección bacteriana. Los resultados demuestran que $S$. sagax caeruleus no toleró un cambio térmico abrupto de más de $4{ }^{\circ} \mathrm{C}$, independientemente de las AT, más del $50 \%$ murió. Las consecuencias del estrés térmico agudo y crónico experimental fueron las alteraciones histopatológicas del hígado y el riñón. Se esperaba que la temperatura de estrés crónica pudiera producir cambios histológicos conspicuos en los peces, y de hecho fue la más perjudicial.

PALABRAS CLAVE: Sardinops sagax caeruleus; Estrés térmico; Histopatología.

\section{REFERENCES}

Anderson, D. P. Immunological indicators: effects of environmental stress on immune protection and disease outbreaks. Am. Fish. Soc. Symp., 8:38-50, 1990

Bakun, A. \& Broad, K. Environmental 'loopholes' and fish population dynamics: comparative pattern recognition with focus on El Niño effects in the Pacific. Fish. Oceanogr., 12(4-5):458-73, 2003.

Barandica, C. L. M. \& Tort, B. L. Neuroendocrinología e inmunología de la respuesta al estrés en peces. Rev. Acad. Colomb. Cienc., 32(123):267-84, 2008.

Beitinger, T. L.; Bennett, W. A. \& McCauley, R. W. temperature tolerances of North American freshwater fishes exposed to dynamic changes in temperature. Environ. Biol. Fish., 58(3):237-75, 2000.

Bhuiyan, A. S.; Nesa, B. \& Nessa, Q. Effects of sumithion on the histological changes of spotted murrel, Channa punctatus (Bloch). Pak. J. Biol. Sci., 4(10):1288-90, 2001.

Brett, J. R. Some principles in the thermal requirements of fishes. Quart. Rev. Biol. 31(2):75-87, 1956.

Chiang, H. L.; Terlecky, S. R.; Plant, C. P. \& Dice, J. F. A role for a 70-kilodalton heat shock protein in lysosomal degradation of intracellular proteins. Science, 246(4928):382-5, 1989.

Committee on the Status of Endangered Wildlife in Canada (COSEWIC). Assessment and update status report on the Pacific sardine Sardinops sagax in Canada. Ottawa, Committee on the Status of Endangered Wildlife in Canada, 2002. pp.7-19.

Cowles, R. B. \& Bogert, C. M. A preliminary study of the thermal requirements of desert reptiles. Bull. Am. Mus. Nat. Hist., 83:5, 1944.

Culley, M. The Pilchard: Biology and Exploitation. Oxford, Pergamon Press Limited, 1971.

Davis, K. B. \& Parker, N. C. Physiological stress in striped bass: effect of acclimation temperature. Aquaculture, 91(3-4):349-58, 1990.

Feder, M. E. \& Hofmann, G. E. Heat-shock proteins, molecular chaperones, and the stress response: evolutionary and ecological physiology. Annu. Rev. Physiol., 61:243-82, 1999.

Félix-Uraga, R.; Gómez-Muñoz, V. M.; Quiñónez-Velázquez, C. \& Melo-Barrera, F. N. On the existence of Pacific sardine groups off the West coast of Baja California and Southern California. CalCOFI Rep., 45:146-51, 2004.

Fernández, A. B.; de Blas, I. \& Ruiz, I. El sistema inmune de los teleósteos (I): Células y órganos. AquaTic, (16), 2002.

Fry, F. E. J.; Brett, J. R. \& Clawson, G. H. Lethal limits of temperature for young goldfish. Rev. Canad. Biol., 1:50-6, 1942.

González de Canales, M. L.; Ortiz-Delgado, J. B. \& Sarasquete, C. Histopathological changes induced by lindane $(\mathrm{g}-\mathrm{HCH})$ in various organs of fishes. Mar. Sci., 67(1):53-61, 2003.

Hammann, M. G.; Baumgartner, T. R. \& Bandan-Dangon, A. Coupling of the Pacific sardine (Sardinops sagax caeuruleus) life cycle with the Gulf of California pelagic environment. CalCOFI Rep., 29:102-8, 1988.

Hinton, D. E. \& Lauren, D. J. Integrative histopathological approaches to detecting effects of environmental stressors on fishes. In: Adams, S. M. (Ed.). Biological Indicators of Stress in Fish. Bethesda, Maryland, American Fisheries Society Symposium, 1990. pp.51-66.
Jacobson, M. D. \& McCarthy, N. Apoptosis the Molecular Biology of Programmed Cell Death. New York, Oxford University Press, 2002.

Kilgour, D. M.; McCauley, R. W. \& Kwain, W. Modeling the lethal effects of high temperature on fish. Can. J. Fish Aquat. Sci., 42(5):947-51, 1985.

Kiryu, Y. \& Moffitt, C. M. Acute LD50 and kidney histopathology following injection of erythromycin (Erythro-200) and its carrier in spring chinook salmon, Oncorhynchus tshawytscha (Walbaum). J. Fish Dis., 24(7):409-16, 2001.

Lagler, K. F.; Bardach, J. E.; Miller, R. R. \& May Passino, D. R. Ictiología. Ciudad de México, AGT Editor S. A., 1984. pp.489.

Lynn, R. J. Variability in the spawning habitat of Pacific sardine (Sardinops sagax) off southern and central California. Fish. Oceanogr., 12(6):541-53, 2003.

Martínez-Porchas, M. \& Hernández-Rodríguez, M. Estimation of the thermal ranges associated with the distribution of Sardinops sagax caeruleus, based on its thermal preference. Rev. Biol. Mar. Oceanogr., 45(3):537-40, 2010.

Martínez-Porchas, M.; Hernández-Rodríguez, M. \& Bückle-Ramirez, L. F. Thermal behavior of the Pacific sardine (Sardinops sagax) acclimated to different thermal cycles. J. Therm. Biol., 34(7):372-6, 2009.

Mayer, C. \& Grummt, I. Cellular stress and nucleolar function. Cell Cycle, 4(8):1036-8, 2005.

Moseley, P. Stress proteins and the immune response. Immunopharmacology, 48(3):299-302, 2000.

Olivereau, M. \& Olivereau, J. Effect of transfer to sea water and back to fresh water on the histological structure of the eel kidney. J. Comp. Physiol., 115(2):223-39, 1977

Paladino, F. V.; Spotilla, J. R.; Schubauer, J. P. \& Kowalski, K. T. The critical thermal maximum: a technique used to elucidate physiological stress and adaptation in fishes. Rev. Can. Biol, 39 (2):115-22, 1980.

Pribyl, A. L.; Hyde, J. R.; Robertson, L. \& Vetter, R. Defining an ideal temperature range for the northern subpopulation of Pacific sardine, Sardinops sagax caeruleus. Environ. Biol. Fish., 99:275-91, 2016.

Rombough, P. J. \& Garside, E. T. Hypoxial death inferred from thermally induced injuries at upper lethal temperatures, in the banded killifish, Fundulus diaphanus (LeSueur). Can. J. Zool., 55(10):1705-19, 1977.

Shaw, B. L. \& Battle, H. I. The gross microscopic anatomy of the digestive tract of the oyster Crassostrea virginica (Gmelin). Can. J. Zool., 35(3):325-47, 1957.

Srivastava, P. K. Roles of heat-shock proteins in innate and adaptive immunity. Nat. Rev. Immunol., 2(3):185-94, 2002.

Studzinski, G. P. Apoptosis a Practical Approach. New York, Oxford University Press, 1999.

Takashima, F. \& Takashi, H. Fish Histology: Normal and Pathological Features. Tokyo, Kodansha Ltd., 1995.

Wedemeyer, G. A. Effects of Rearing Conditions On Health and Physiological Condition of Fish in Intensive Culture. In: Iwama, G. K.; Pickering, A. D.; Sumpter, J. P. \& Schreck, C. B. (Eds.). Fish, Stress and Health in Aquaculture. Cambridge, Cambridge University Press, 1997.

Zacarías, M.; Cadena, M. \& Rivas, P. Structural Modifications in the stomach and liver of Paralabrax maculatofasciatus (Steindacher, 1868) under chronic stress conditions. Int. J. Morphol., 27(2):425-33, 2009.

Ziegeweid, J. R.; Jennings, C. A. \& Peterson, D. L. Thermal maxima for juvenile shortnose sturgeon acclimated to different temperatures. Environ. Biol. Fish., 82:299-307, 2008.

Corresponding author:

Dra. Mónica Hernández Rodríguez

Department of Aquaculture

P.O. Box: 434844

San Diego, CA. 921434844

USA

Email: mhernand@cicese.mx

Received: 17-08-2017

Accepted: 24-10-2017 